\title{
Mineralogy and preliminary assessment of the potential uses of alluvial clays from Batouri (Eastern-Cameroon)
}

\section{(Mineralogia e avaliação preliminar dos potenciais usos de argilas aluviais de Batouri - Leste de Camarões)}

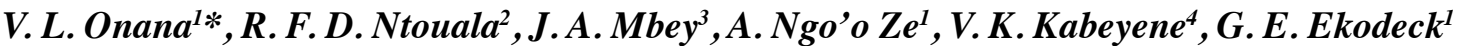 \\ ${ }^{1}$ University of Yaoundé I, Faculty of Science, Department of Earth Sciences, P.O. Box 812, Yaoundé, Cameroon \\ ${ }^{2}$ University of Maroua, Faculty of Mines and Petroleum Industries, Department of Mining Engineering and \\ Mineral Processing, Maroua, Cameroon \\ ${ }^{3}$ University of Yaoundé I, Faculty of Science, Department of Inorganic Chemistry, Yaoundé, Cameroon \\ ${ }^{4}$ University of Yaoundé I, Higher Teacher's Training College, Department of Geology, Yaoundé, Cameroon
}

\begin{abstract}
This study aimed at assessing the potential uses of alluvial clayey materials from Batouri. Their mineralogical, chemical and some physicomechanical characteristics are presented with some characteristics of fired bricks at $900,950,1000,1050$ and $1100{ }^{\circ} \mathrm{C}$. The raw materials consisted of kaolinite, quartz, K-feldspars, anatase, and goethite. The phases formed during the firing process were mullite, quartz, hematite, and anatase. The linear shrinkage increased with firing temperature and remained $<12 \%$ while water absorption decreased and remained $<25 \%$. Flexural strength increased due to the formation of dense phases (especially mullite) and, except for one sample, was at least $2 \mathrm{MPa}$. The SEM micrographs showed cracks that accounted for overall moderate mechanical responses. For firing above $1000{ }^{\circ} \mathrm{C}$, the flexural strength of the three samples makes them usable as raw materials for roofing tiles manufacturing if the convenient amendment is done. The overall properties highlighted that all the studied materials are usable for brick manufacturing.
\end{abstract}

Keywords: alluvial clays, kaolinite, mineralogy, flexural strength, clay bricks, roofing tiles.

\section{Resumo}

Este estudo teve como objetivo avaliar os usos potenciais de materiais argilosos aluviais de Batouri. Suas características mineralógicas, químicas e algumas físico-mecânicas são apresentadas, bem como algumas características de tijolos queimados em 900, 950, 1000, 1050 e $1100{ }^{\circ} \mathrm{C}$. As matérias-primas consistiram de caulinita, quartzo, feldspato potássico, anatásio e goetita. As fases formadas durante o processo de queima foram mulita, quartzo, hematita e anatásio. A retração linear aumentou com a temperatura de queima e permaneceu $<12 \%$, enquanto a absorção de água diminuiu e permaneceu $<25 \%$. A resistência à flexão aumentou devido à formação de fases densas (especialmente mulita) e, com exceção de uma amostra, foi de pelo menos 2 MPa. As micrografias de MEV mostraram trincas que foram responsáveis por respostas mecânicas moderadas. Para queima acima de $1000{ }^{\circ} \mathrm{C}$, três amostras apresentaram resistência à flexão que as tornam utilizáveis como matérias-primas para a fabricação de telhas, se for convenientemente preparada. As propriedades gerais destacaram que todos os materiais estudados são utilizáveis para fabricação de tijolos.

Palavras-chave: argilas aluviais, caulinita, mineralogia, resistência à flexão, tijolos de argila, telhas.

\section{INTRODUCTION}

Clays are widely used in various fields including ceramics, paints, agriculture, composite materials, health, and environmental issues. Ceramics stand as one of the most usual domains in which clays are used. The type and the quality of the end products depend on the sample characteristics such as mineralogy, physicochemical properties and chemical composition [1-6]. Amongst clays, kaolinite-rich clay deposits are widely spread and their

*onana.vl@gmail.com

(D) https://orcid.org/0000-0003-4930-7065 occurrences are large in Cameroon [7]. These materials are widely used by the local population as building materials. For this purpose, proper characterization of the raw materials is necessary in order to improve product quality. This is why many studies are being conducted on clay characterization [8-14]. The need to properly characterize the available materials, in order to conveniently define the possible enduses of the raw materials or to improve quality of products derived from these resources is still of importance given that each deposit has a unique chemical and mineralogical feature. In addition, it is well-known that the sale of raw materials does not economically improve low-income countries. Hence, providing scientific quality information 
on the raw materials so as to boost their industrial uses at a national scale and beyond, may generate more income. Due to their low-cost and their availability, clays are relatively cheap and sustainable resources to improve the building capacity of underdeveloped countries. It is now well-established that clay-based building materials such as bricks are cost effective and also technologically affordable [15-17]. However, in the case of fired bricks, care should be given to the energy type and source, in order to control environmental impact due to traditional practices [18].

Batouri, a locality of East of Cameroon, is characterized by the exploitation of alluvial gold deposit [19-21]. The alluvial clays are widespread in this region. The vast deposits of alluvial materials generated are sterile which utilization has to be identified in other to avoid or limit the environmental constraints associated with their accumulation [22]. Clay minerals are the main constituents of this alluvial material and the studies on their properties and potential uses are still scarce [13]. The aim of this study is to characterize these clayey materials in relation to their potential application for ceramic material manufacturing. In particular, the scientific information generated from this study is expected to serve as a basis to improve the utilization of these clays as building materials. To this effect, raw materials and fired products from 900 to $1100{ }^{\circ} \mathrm{C}$ were characterized. The mineralogical, chemical and physicomechanical properties of the raw materials were analyzed. Flexural strength, water absorption and linear shrinkage of the fired products were evaluated, and the morphological features (using a scanning electron microscope, SEM) of some fired products were also examined.

\section{MATERIALS AND METHODS}

Clay materials: nine alluvial clay samples were collected in localities around Batouri and were indexed as MBE, KAM, TAP, NGO, SAN, DOG1, TRY, DOG and WAN. The sampling points are depicted in Fig. 1. The sampling was done using a manual auger at 1-1.5 m deep. The collected samples (about $50 \mathrm{~kg}$ ) were ground and sieved over a $250 \mu \mathrm{m}$ sieve and kept in polyethylene bags prior to their use. About $50 \mathrm{~g}$ of each sample was analyzed.

Analytical techniques: the mineralogy of the samples was accessed by powder X-ray diffraction (XRD), using samples crushed and sieved at $250 \mu \mathrm{m}$, on a PANalytical X'pert PRO diffractometer equipped with $\operatorname{CoK} \alpha$ radiation $(\lambda=1.7890 \AA)$. The mineralogy of fired samples was recorded using a Bruker D2 Phaser diffractometer equipped with $\mathrm{CuK} \alpha$ radiation (1.5718 ̊) operating at $30 \mathrm{kV}$. The patterns were recorded with a step rate of $0.01 \%$ s over a $2 \theta$ range of $5^{\circ}$ to $70^{\circ}$. Infrared spectra were recorded in diffuse reflectance mode using a Bruker Alpha-P Fourier-transform interferometer. The spectra were recorded from 4000 to $400 \mathrm{~cm}^{-1}$ with a resolution step of $4 \mathrm{~cm}^{-1}$. The chemical analysis for major elements was done after sample ignition by X-ray fluorescence spectroscopy on PANalytical Axios Advanced PW 4400 equipment. The samples were run for loss on ignition (LOI, $105{ }^{\circ} \mathrm{C}$ under

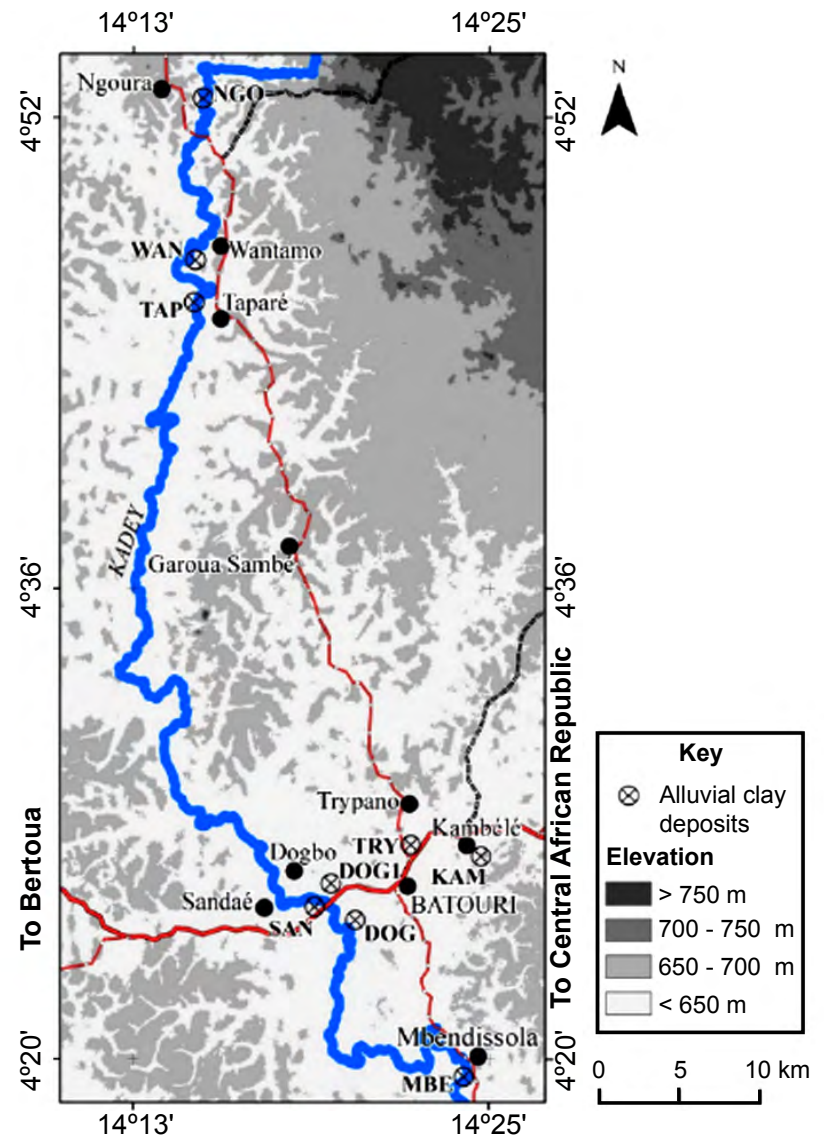

Figure 1: Location of clay samples in the Batouri area, EastCameroon (adapted from NB-33-III-1c and NB-33-III-1d topographic maps of Batouri, Institut Géographique National IGN, 1972).

[Figura 1: Localização das amostras de argila na área de Batouri, Leste de Camarões (adaptado dos mapas topográficos NB-33-III1c e NB-33-III-1d de Batouri, Institut Géographique National IGN, 1972).]

nitrogen atmosphere, $1000{ }^{\circ} \mathrm{C}$ under oxygen atmosphere). The calcined samples were then melted with a borate flux to produce a glass bead for analysis. The total content of each element was expressed as its oxide. Titration with standard permanganate solution was used for iron (II) oxide (FeO) after dissolving in an aggressive nonoxidative acid. All analyses were certified in ISO 9001. The SEM micrographs were obtained on Tescan Mira LMU microscope operated at an acceleration voltage of $20 \mathrm{kV}$ and a probe current of $\sim 0.5 \mathrm{nA}$. The samples were coated with carbon and a secondary electron detector was used for the imaging. The color of the dry samples and fired samples were determined using the Munsell soil color chart. The particle size data were obtained by sieving (AFNOR, 1996) for sizes greater than $80 \mu \mathrm{m}$ and by sedimentation (AFNOR, 1992) for sizes less than $80 \mu \mathrm{m}$. The liquid limit (LL) was measured by the Casagrande dish method and the plastic limit (PL) by the roller method. The measurements were performed according to ASTM D4318-2005 standard. Plasticity index (PI) was calculated as the difference between LL and PL. 
For each sample, four test briquettes with length $\mathrm{x}$ width $\mathrm{x}$ thickness dimensions of $8 \times 4 \times 1.5 \mathrm{~cm}$ were elaborated using a laboratory hydraulic press. For each briquette, a mixture of $100 \mathrm{~g}$ of clay associated with $17-20 \%$ water (on dry basis) was used. The formulated test bricks were air-dried for 7 days, then oven-dried at $105{ }^{\circ} \mathrm{C}$ for $24 \mathrm{~h}$ to remove moisture before firing. The firing was done in a muffle furnace. The briquettes were subjected to five firing temperatures: 900 , $950,1000,1050$ and $1100{ }^{\circ} \mathrm{C}$. These temperatures were chosen according to the proposed economically practical temperature range of 1000 to $1200{ }^{\circ} \mathrm{C}$, suggested by the South African Clay Brick Association [23]. For all firing cycles, the heating rate was $5{ }^{\circ} \mathrm{C} / \mathrm{min}$ and soaking time of $2 \mathrm{~h}$ at the required temperature was adopted before furnace cooling to room temperature. The linear shrinkage (LS) was determined using the equation (ASTM C531-2000):

$$
\operatorname{LS}(\%)=\left[\left(\mathrm{L}_{0}-\mathrm{L}_{1}\right) / \mathrm{L}_{0}\right] \cdot 100
$$

where $\mathrm{L}_{0}$ is the initial length $(\mathrm{mm})$ of the brick after drying at $105{ }^{\circ} \mathrm{C}$ for $24 \mathrm{~h}$ and $\mathrm{L}_{1}$ the length $(\mathrm{mm})$ after firing. The water absorption (WA) was evaluated according to the ASTM C20-2000 standard:

$$
\mathrm{WA}(\%)=\left[\left(\mathrm{W}_{2}-\mathrm{W}_{1}\right) / \mathrm{W}_{1}\right] \cdot 100
$$

where $\mathrm{W}_{2}$ is the mass of the $24 \mathrm{~h}$ water-soaked specimen and $\mathrm{W}_{1}$ is the mass of the dry fired briquette. The flexural strength value $(\sigma)$ was evaluated according to ASTM F4171996 standard for each test briquette, following the equation:

$$
\sigma=3 \cdot P \cdot L /\left(2 \cdot 1 \cdot h^{2}\right)
$$

where $\mathrm{P}$ is the load at fracture $(\mathrm{N}), \mathrm{L}$ is the distance between supporting knife edge $(50 \mathrm{~mm}), 1$ is the width of the briquette, and $h$ is the thickness of the briquette (mm).

\section{RESULTS AND DISCUSSION}

Mineralogical and chemical composition: the XRD patterns (Fig. 2) indicated the presence of kaolinite, quartz, $\mathrm{K}$-feldspars, anatase, and goethite as main minerals. Kaolinite is the main clay mineral associated primarily to quartz. The relatively high intensity of the quartz peaks in

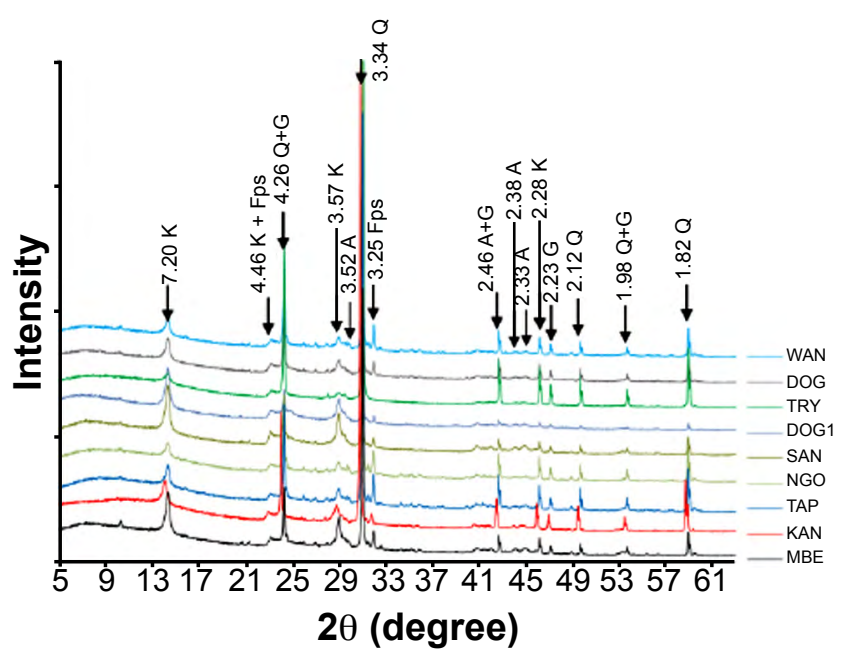

Figure 2: XRD patterns of the studied samples. K-kaolinite, Q-quartz, Fps-K-feldspars, A-anatase, G-goethite.

[Figura 2: Padrões de DRX das amostras estudadas. K-caulinita, $Q$-quartzo, Fps-feldspato de K, A-anatásio, G-goetita.]

\begin{tabular}{|c|c|c|c|c|c|c|c|c|c|c|}
\hline Sample & d.1. & DOG & DOG1 & KAM & MBE & NGO & SAN & TAP & TRY & WAN \\
\hline $\mathrm{SiO}_{2}$ & 0.01 & 62.20 & 47.36 & 71.65 & 58.67 & 68.53 & 52.94 & 70.36 & 76.10 & 65.23 \\
\hline $\mathrm{TiO}_{2}$ & 0.01 & 1.73 & 1.99 & 1.33 & 2.00 & 1.53 & 2.13 & 1.45 & 1.15 & 1.77 \\
\hline $\mathrm{Al}_{2} \mathrm{O}_{3}$ & 0.01 & 20.87 & 25.74 & 15.45 & 22.57 & 16.67 & 25.87 & 15.81 & 13.69 & 18.80 \\
\hline $\mathrm{Fe}_{2} \mathrm{O}_{3}$ & 0.01 & 2.77 & 9.68 & 1.72 & 2.66 & 1.66 & 3.58 & 2.57 & 0.93 & 2.33 \\
\hline $\mathrm{FeO}$ & 0.01 & 0.28 & 0.20 & 0.23 & 0.42 & 0.28 & 0.41 & 0.30 & 0.36 & 0.33 \\
\hline $\mathrm{MnO}$ & 0.002 & 0.016 & 0.012 & 0.012 & 0.017 & 0.015 & 0.016 & 0.018 & 0.016 & 0.016 \\
\hline $\mathrm{MgO}$ & 0.01 & 0.28 & 0.29 & 0.35 & 0.33 & 0.21 & 0.29 & 0.20 & 0.09 & 0.21 \\
\hline $\mathrm{CaO}$ & 0.006 & 0.074 & 0.087 & 0.0146 & 0.115 & 0.099 & 0.045 & 0.118 & 0.046 & 0.090 \\
\hline $\mathrm{Na}_{2} \mathrm{O}$ & 0.02 & 0.06 & 0.03 & 0.04 & 0.10 & 0.14 & $<0.02$ & 0.15 & $<0.02$ & 0.12 \\
\hline $\mathrm{K}_{2} \mathrm{O}$ & 0.01 & 1.27 & 0.67 & 1.04 & 1.79 & 2.10 & 1.09 & 2.10 & 0.08 & 1.93 \\
\hline $\mathrm{P}_{2} \mathrm{O}_{5}$ & 0.002 & 0.078 & 0.184 & 0.060 & 0.115 & 0.078 & 0.080 & 0.070 & 0.033 & 0.079 \\
\hline LOI & 0.05 & 9.77 & 13.26 & 7.39 & 10.65 & 7.68 & 12.87 & 6.92 & 7.10 & 8.85 \\
\hline Total & - & 99.40 & 99.51 & 99.29 & 99.44 & 98.99 & 99.32 & 100.07 & 99.60 & 99.76 \\
\hline $\mathrm{SiO}_{2} / \mathrm{Al}_{2} \mathrm{O}_{3}$ & & 2.98 & 1.84 & 4.64 & 2.60 & 4.11 & 2.05 & 4.45 & 5.56 & 3.47 \\
\hline
\end{tabular}

Table I - Chemical compositions (wt \%) of alluvial clays from Batouri region.

[Tabela I - Composições químicas (\% em massa) de argilas aluviais da região de Batouri.]

d.l.: detection limit 


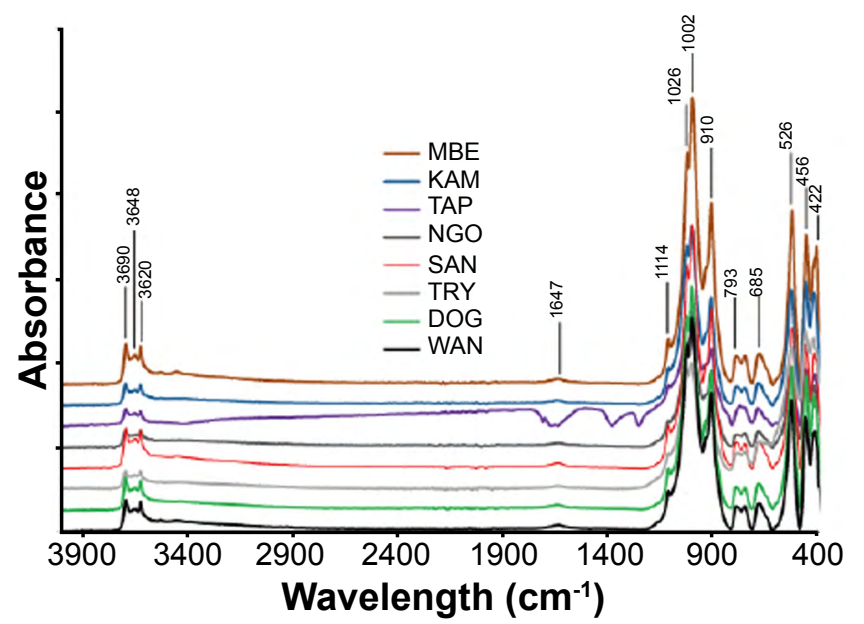

Figure 3: Infrared spectra of the studied samples.

[Figura 3: Espectros no infravermelho das amostras estudadas.]

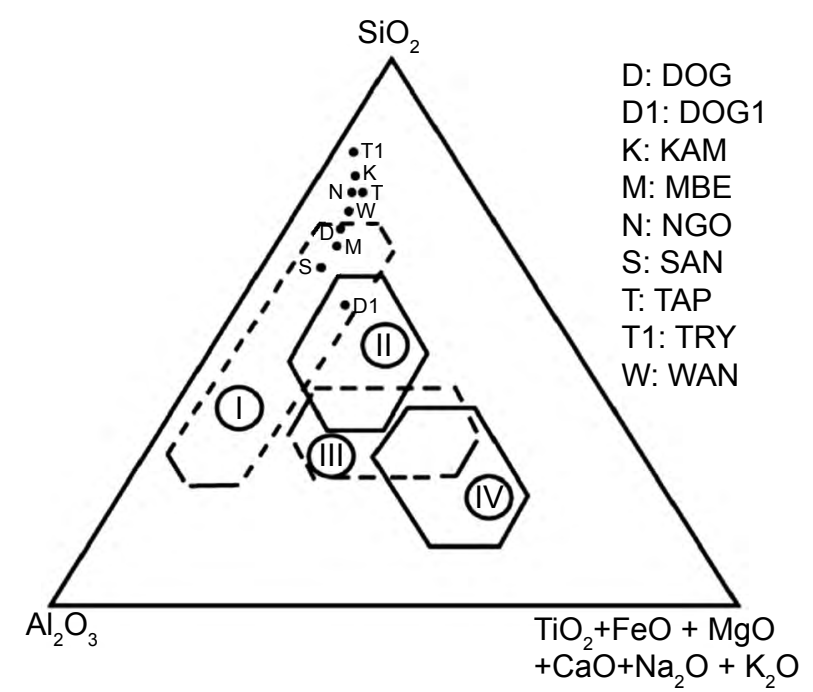

Figure 4: Fields of suitable chemical compositions for manufacturing various ceramic products: I) white stoneware tiles; II) red stoneware tiles; III) cottoforte; IV) majolica (adapted from [29]).

[Figura 4: Campos de composições químicas adequados para manufatura de vários produtos cerâmicos: I) revestimentos de grês brancos; II) revestimentos de grês vermelhos; III) cottoforte; IV) maiólica (adaptado de [29]).]

the XRD patterns of these materials indicated a significant presence of this mineral [24]. This was confirmed by the high $\mathrm{SiO}_{2} / \mathrm{Al}_{2} \mathrm{O}_{3}$ ratios (Table I); the $\mathrm{Al}_{2} \mathrm{O}_{3}$ content was associated with the presence of clayey minerals, mainly kaolinite. The LOI values were coherent with the kaolinitic nature of the samples [25]. The presence of $\mathrm{K}_{2} \mathrm{O}$ was linked to the presence of $\mathrm{K}$-feldspars. $\mathrm{TiO}_{2}$ and $\mathrm{Fe}_{2} \mathrm{O}_{3}$ contents were related to the presence of anatase and goethite in these materials. The chemical composition was coherent with the mineralogy. The contents of fluxing oxides $\left(\mathrm{Na}_{2} \mathrm{O}, \mathrm{K}_{2} \mathrm{O}, \mathrm{CaO}\right.$, and $\left.\mathrm{MgO}\right)$ were very low and might cause insufficient sintering during firing due to poor vitreous phase formation. These clays have poor iron content and are of interest in formulating flat tiles in mixture with flux-rich clay $[13,14]$. The infrared spectra (Fig. 3) were typical of kaolinite minerals confirming the XRD analysis. The characteristics bands at 3690, 3648 and $3620 \mathrm{~cm}^{-1}$ are the stretching bands of $\mathrm{O}-\mathrm{H}$ bonds in the kaolinite structure. The band at $3690 \mathrm{~cm}^{-1}$ was assigned to surface $\mathrm{O}-\mathrm{H}$, in-phase stretching vibration; the band at $3648 \mathrm{~cm}^{-1}$ was attributed to the surface O-H, out-of-phase stretching vibration and the band at $3620 \mathrm{~cm}^{-1}$ is known as the inner O-H stretching vibration $[26,27]$. The band at 1647 $\mathrm{cm}^{-1}$ was assigned to the group vibration of hydration water molecules within the samples. The Si-O stretching at 1114 $\mathrm{cm}^{-1}$, Si-O-Si skeleton stretching vibration at $1026 \mathrm{~cm}^{-1}$, the bending vibration of $\mathrm{Al}-\mathrm{OH}$ at $910 \mathrm{~cm}^{-1}$ and the $-\mathrm{OH}(\mathrm{Al}-$ $\mathrm{OH})$ translational vibration at 785 and $685 \mathrm{~cm}^{-1}$ were also observed [28]. The presence of these bands was coherent with the quartz-rich nature of these clays. Plotting the chemical composition of the studied samples in the ternary diagram presented in Fig. 4, it was found that DOG, DOG1, MBE, and SAN are suitable for stoneware tiles. Due to the $\mathrm{Fe}_{2} \mathrm{O}_{3}$ content of the sample DOG1, red stoneware can be formed. The content of iron and titanium oxides for the other samples may favor shaded colors for the fired products. The other samples appear to be silica-rich and may be used in mixture with clay-rich samples.

Physical analyses of raw samples, mineralogical and mechanical characterization of the fired products: the liquid limit (LL), plasticity limit (PL), and plasticity index (PI) values are listed in Table II. Liquid limit values ranged between 27\% (KAM) and 56\% (DOG1) whereas PL values varied from $17 \%$ (KAM) to $40 \%$ (SAN), and the PI values from $5 \%$ (NGO) to $18 \%$ (DOG). The projection of the materials' PL and PI in the workability chart (Fig. 5) showed that the samples had acceptable molding properties except for SAN, DOG1 and NGO. The linear shrinkage upon the firing of SAN and DOG1 appeared as the parameter to be controlled via amendment prior to its processing. Due to the low cohesion risks, $\mathrm{NGO}$ and TAP may also need amendment; given that from Table II these samples had low clay contents, the amendment should consist of clay fraction enrichment to reinforce grain cohesion. Batouri's alluvial deposits mainly consisted of clays, silts, and sands (Table II). All the samples were almost gravel free; only DOG1 had a significant gravel content (6.31 wt\%). Clay content was greater than $30 \%$ with SAN being the richest ( $65 \%$ clay content). The percentage of sand was moderate in all samples except for TRY where it was significant and, associated with its poorest silt content $(3.9 \%)$, may affect its direct use in brick manufacturing. These clays were classified as sandy clays in the Belgian textural diagram. When projected in the Winkler's diagram (Fig. 6), the particle size distribution (PSD) of these clays indicated that DOG, MBE, NGO, and TAP were appropriate for roofing tiles and masonry bricks while WAN PSD was favorable for hollow products. Some of them, such as DOG1, SAN and TRY, may need amendment before use. In addition, KAM was also usable for vertically perforated bricks. Sample SAN was the richest clay sample and could be used for clay content amendment with other samples while TRY, because of its sand content, may be used for sand amendment. 
Table II - Physical properties of alluvial clays from Batouri region.

[Tabela II - Propriedades físicas de argilas aluviais da região de Batouri.]

\begin{tabular}{ccccccccccc}
\hline Property & Ref. code & DOG & DOG1 & KAM & MBE & NGO & SAN & TAP & TRY & WAN \\
\hline \multirow{4}{*}{ Plasticity } & LL (\%) & 42 & 56 & 27 & 47 & 29 & 54 & 31 & 40 & 43 \\
& PL (\%) & 24 & 39 & 17 & 31 & 24 & 40 & 23 & 24 & 29 \\
& PI (\%) & 18 & 17 & 10 & 16 & 5 & 14 & 8 & 16 & 14 \\
\hline \multirow{6}{*}{ PSD (wt\%) } & Gravel & 0.03 & 6.31 & 0.13 & 0.00 & 0.00 & 0.03 & 0.02 & 0.90 & 0.00 \\
& Sand & 27.30 & 20.96 & 54.47 & 20.20 & 50.60 & 13.06 & 41.92 & 58.90 & 28.80 \\
& Silt & 18.27 & 16.80 & 11.74 & 28.30 & 19.37 & 21.70 & 22.44 & 3.90 & 24.40 \\
& Clay & 54.40 & 55.93 & 33.66 & 51.50 & 30.03 & 65.21 & 35.62 & 36.30 & 46.80 \\
\hline \multicolumn{2}{c}{ VBS (g/100 g) } & 1.53 & 2.53 & 2.27 & 1.60 & 1.60 & 2.13 & 1.13 & 0.73 & 1.47 \\
\hline
\end{tabular}

Note: LL-liquid limit; PL-plasticity limit; PI-plasticity index; PSD-particle size distribution.

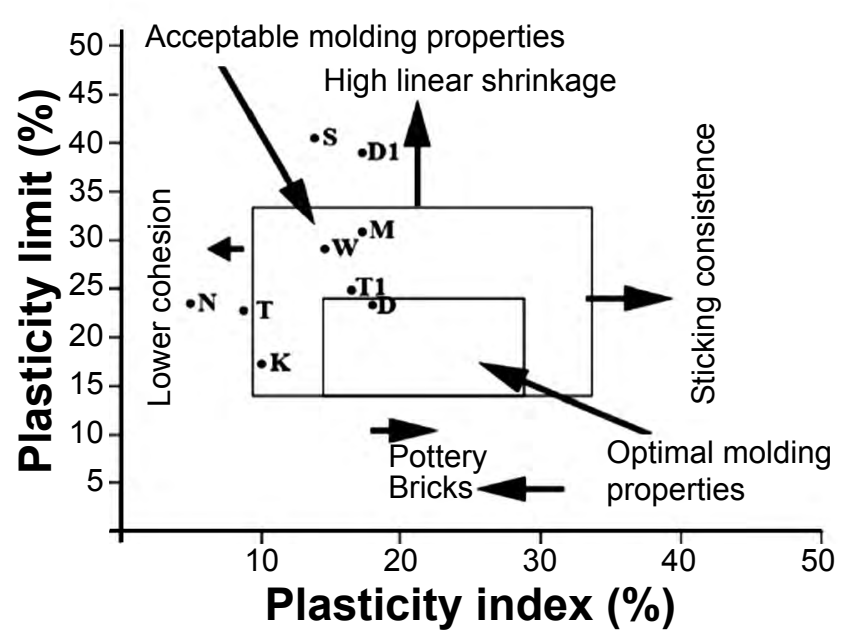

$\begin{array}{lllll}\text { D: DOG } & \text { K: KAM } & \text { N: NGO } & \text { T: TAP } & \text { W: WAN } \\ \text { D1: DOG1 } & \text { M: MBE } & \text { S: SAN } & \text { T1: TRY } & \end{array}$

Figure 5: Workability chart (adapted from [30]).

[Figura 5: Diagrama de trabalhabilidade (adaptado de [30]).]

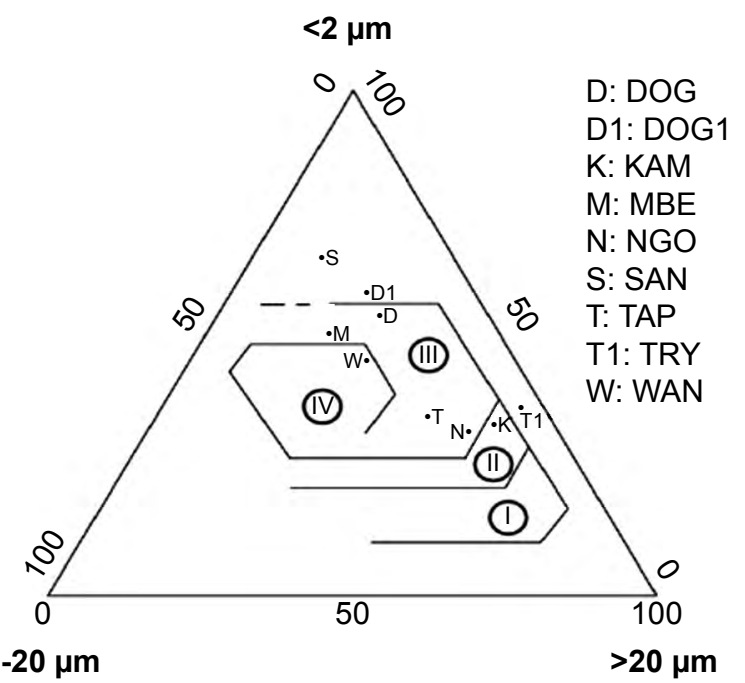

Figure 6: Winkler diagram: I) common bricks; II) vertically perforated bricks; III) roofing tiles and masonry bricks; and IV) hollow products.

[Figura 6: Diagrama de Winkler: I) tijolos maciços; II) tijolos furados; III) telhas e tijolos de alvenaria; e IV) produtos ocos.]
The fired brick colors (Fig. 7 and Table III) were pinkish white, pink, reddish yellow, light red, red and very pale brown according to Munsell color chart. The color of the fired products was mainly affected by the iron mineral (namely goethite) whose conversion to hematite (between 250 and $300{ }^{\circ} \mathrm{C}$ ) is responsible for the reddish, pinkish or brownish aspect of the fired product. The XRD patterns of the fired products (Fig. 8) showed the formation of mullite as from $900{ }^{\circ} \mathrm{C}$. The other minerals were quartz and hematite which also accounted for increased densification. Mullite and hematite peaks were better developed as the firing temperature increased, as also reported on ceramic products of the alluvial clastic clays from the Ngog-Lituba region in Southern Cameroon [31]. This mullite development was in line with the increase of flexural strength upon the increase of firing temperature (Fig. 9).

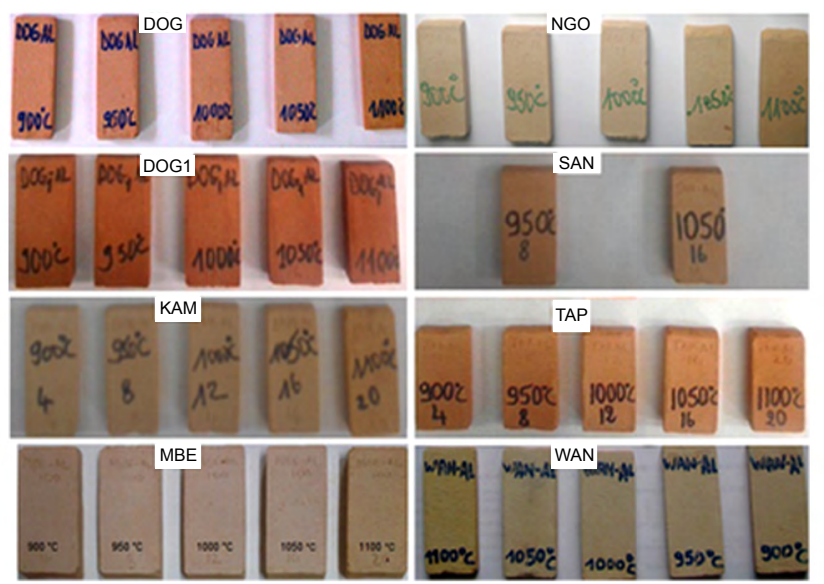

Figure 7: Visual aspect of some fired products.

[Figura 7: Aspecto visual de alguns produtos queimados.]

The linear shrinkage (LS) values increased with firing temperature (Fig. 9a) for all the samples. The highest shrinkage values were registered for DOG1 followed by SAN in accordance with the workability chart information (Fig. 5) and confirmed the need for amendment for shrinkage control. This amendment may consist of silt or sand enrichment that may help dimensional control. This high 
Table III - Munsell code (color) of fired bricks prepared with alluvial clays from Batouri region.

[Tabela III - Código (cor) de Munsell de tijolos queimados preparados com argilas aluviais da região de Batouri.]

\begin{tabular}{cccccccccc}
\hline $\mathrm{T}\left({ }^{\circ} \mathrm{C}\right)$ & DOG & DOG1 & KAM & MBE & NGO & SAN & TAP & TRY & WAN \\
\hline 900 & $7.5 Y R 8 / 4$ & $2.5 Y R 6 / 8$ & $5 Y R 8 / 2$ & $7.5 Y R 8 / 4$ & $7.5 Y R 8 / 4$ & $5 Y R 8 / 4$ & $5 Y R 8 / 4$ & $10 Y R 8 / 2$ & $7.5 Y R 8 / 3$ \\
950 & $5 Y R 8 / 4$ & $2.5 Y R 6 / 8$ & $5 Y R 8 / 2$ & $7.5 Y R 8 / 4$ & $7.5 Y R 8 / 3$ & $5 Y R 8 / 4$ & $5 Y R 8 / 4$ & $10 Y R 8 / 2$ & $7.5 Y R 8 / 4$ \\
1000 & $5 Y R 8 / 4$ & $2.5 Y R 6 / 6$ & $5 Y R 8 / 2$ & $7.5 Y R 8 / 4$ & $7.5 Y R 8 / 4$ & $5 Y R 8 / 4$ & $5 Y R 8 / 4$ & $10 Y R 8 / 2$ & $10 Y R 8 / 3$ \\
1050 & $5 Y R 8 / 4$ & $2.5 Y R 6 / 6$ & $10 Y R 8 / 3$ & $7.5 Y R 8 / 4$ & $10 Y R 8 / 4$ & $7.5 Y R 7 / 6$ & $5 Y R 8 / 4$ & $10 Y R 8 / 2$ & $10 Y R 8 / 3$ \\
1100 & $7.5 Y R 7 / 4$ & $2.5 Y R 4 / 8$ & $10 Y R 8 / 4$ & $7.5 Y R 8 / 6$ & $10 Y R 8 / 6$ & $7.5 Y R 7 / 6$ & $5 Y R 7 / 6$ & $10 Y R 8 / 2$ & $10 Y R 8 / 3$ \\
\hline
\end{tabular}
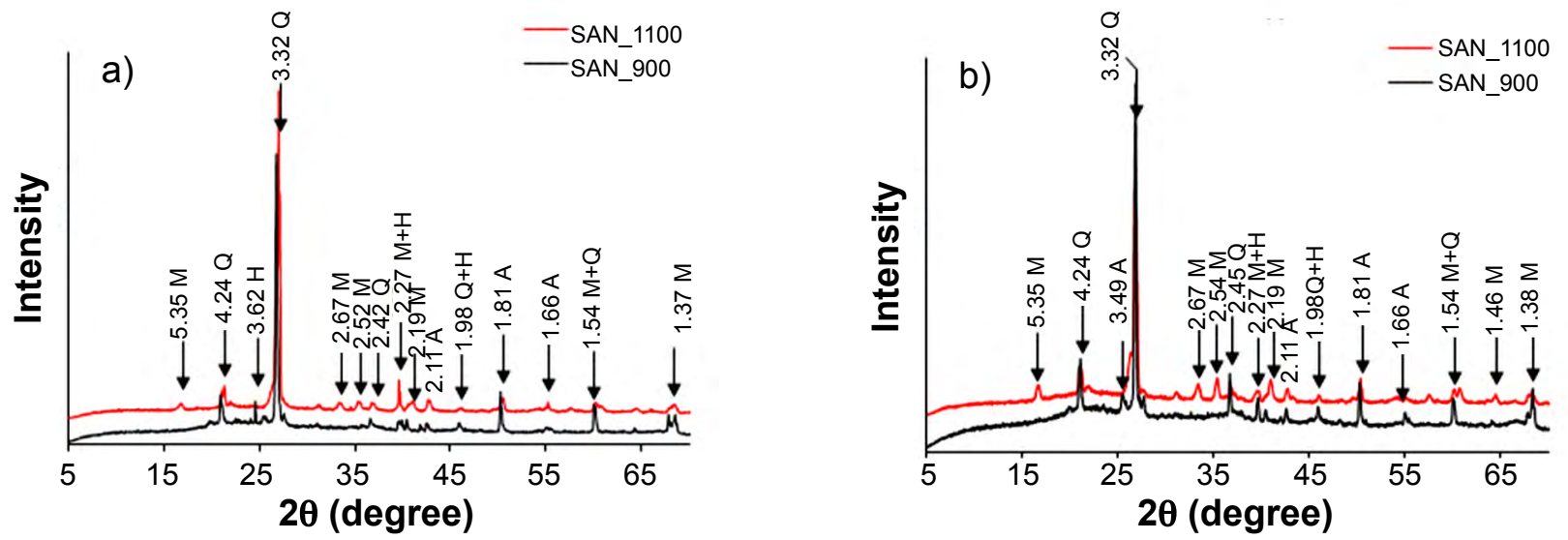

Figure 8: XRD patterns of some products fired at 900 and $1100{ }^{\circ} \mathrm{C}$ for samples DOG (a) and SAN (b). M-mullite; H-hematite; A-anatase; Q-quartz.

[Figura 8: Padrões de DRX de alguns produtos queimados a 900 e $1100{ }^{\circ} \mathrm{C}$ para amostras DOG (a) e SAN (b). M-mulita; H-hematita; A-anatásio; $Q$-quartzo.]

shrinkage was coherent with their high clay content (Table II). The LS values were less than 5\% for DOG, KAM, MBE, NGO, TAP, TRY and WAN at all tested temperatures (Fig. 9a). Regarding their workability (Fig. 5), this lower shrinkage was coherent with their positioning in the acceptable molding properties domain. Considering the PSD (Table II), this low shrinkage was also associated to the sandy nature of the sample in which free silica (sand) acted as a filler and also induced shrinkage control [11]. This explained the fact that clays with a high amount of sand showed less shrinkage of the ceramic products (KAM, NGO, TAP and TRY). Conversely, low quartz contents in SAN and DOG1 accounted for higher shrinkage. High and rapid shrinkage is favorable to the formation of cracks on the fired product as observed on the micrographs of SAN and DOG based fired products (Fig. 10). Also, capillary diffusion of the excess water out of the product structure can contribute to shrinkage [23].

Water absorption (WA) values were lower than $25 \%$ for all the studied materials and at all the tested temperatures (Fig. $9 b)$. The water absorption values decreased with the increase of the firing temperature. The same trend was observed for kaolin from Mankon (NW Cameroon) [32]. The lowest water absorption value was registered for sample SAN. This low water uptake was obviously associated with the sample clay content, which conversion into mullite during firing hindered the water uptake. The lower decrease of water absorption values upon the increase of firing temperature was registered for samples KAM and TRY $(<2 \%)$ while the highest decrease was registered for samples DOG1 and MBE (nearly 8\%). Generally, there was a low decrease of water absorption values in all the samples which was probably due to the absence or very low vitreous phase formation and this was coherent with the low amounts of fluxing agents in all the samples (Table I). For all samples, the highest decrease of water absorption values was registered above $1000{ }^{\circ} \mathrm{C}$ and it was in line with the enhancement of sintering which was associated to the start of the vitreous phase formation (even low) within the ceramic body. The vitreous phase formed caused the enclosure of the pores or the isolation of neighboring pores through the penetration of the liquid vitreous phase within the pores $[2,33]$. The specified values for WA of Brazilian clay-based products [34] are WA $<25 \mathrm{wt} \%$ for dense bricks and WA $<20 \mathrm{wt} \%$ for roofing tiles. Comparing the results of this study with the above standard, dense bricks specification was obtained for all the temperatures considered in this study; roofing tiles specification met only at 1050 and $1100{ }^{\circ} \mathrm{C}$ for DOG1 and MBE and at all temperatures for the other samples. Hence, all the samples could be used for dense brick manufacturing.

Flexural strength values (Fig. 9c) increased with the firing temperature for all the materials. The increase was coherent with the conversion of metakaolinite into mullite upon temperature increase [32], as shown by the XRD of the 

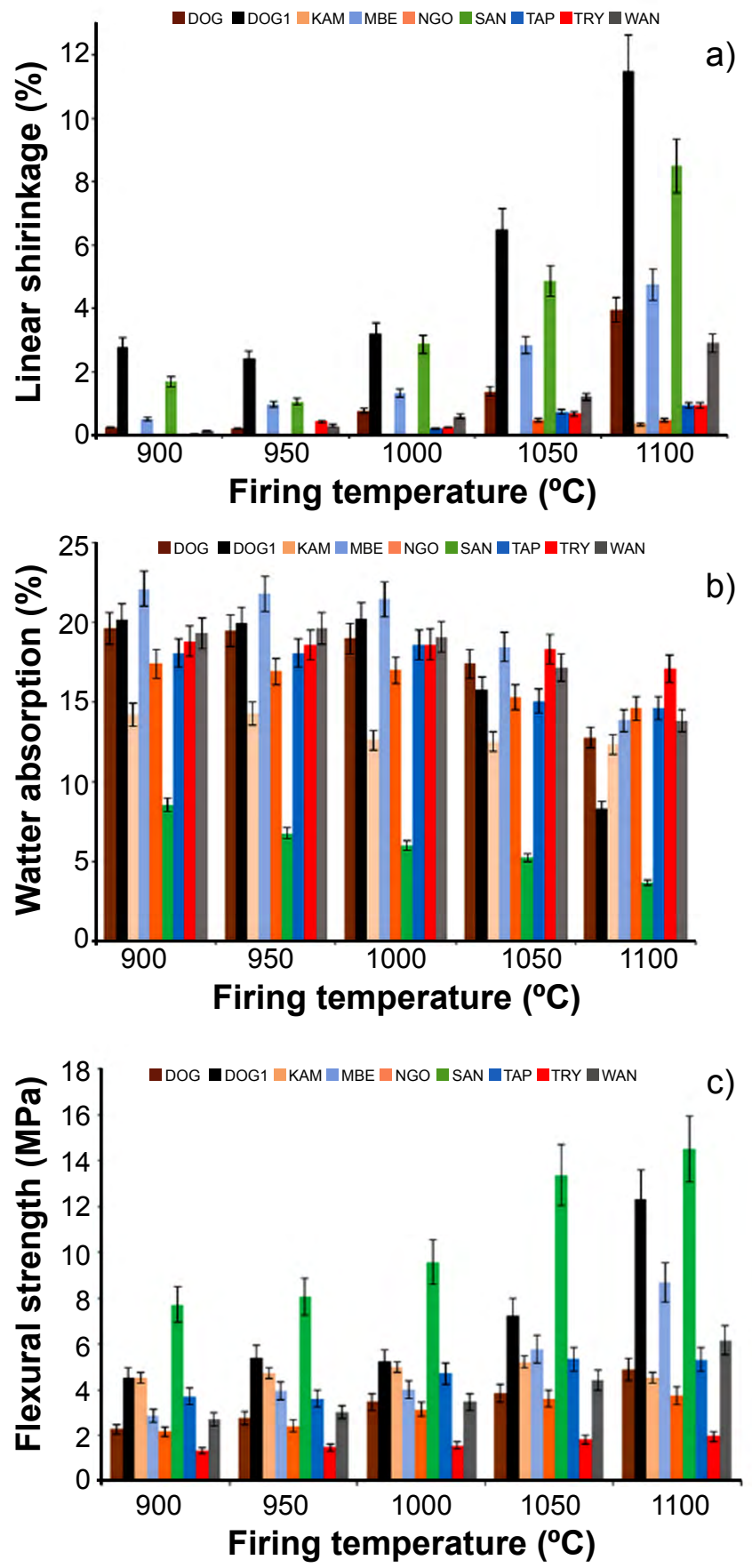

Figure 9: Physical and mechanical properties of the fired products: a) linear shrinkage; b) water adsorption; and c) flexural strength. [Figura 9: Propriedades físicas e mecânicas dos produtos queimados: a) retração linear; b) adsorção de água; $e$ c) resistência à flexão.]

fired products (Fig. 7). The densification brought by mullite associated with quartz and hematite was responsible for the increase in flexural strength. For KAM and TRY materials, the flexural strength values were maximal as from $1050^{\circ} \mathrm{C}$. In general, this increase was moderate and was due to poor or lack of vitreous phase formation within the samples. SAN samples exhibited the highest increase in flexural strength values that was associated with the increase in densification due to high shrinkage and improved densification associated with the conversion of its clay into mullite. Also, the high clay content in SAN was favorable to grain cohesion and also reduced porosity and this accounted for the lowest water uptake of this sample when compared to others (Fig. 9b). The improved densification of SAN samples was obvious from the SEM images (Fig. 10b), which showed a more homogeneous and compact surface feature with smaller cracks. The reduction of cracks and pores in the product accounted for the improvement of mechanical strength [2]. The flexural strength values were poor ( $<2 \mathrm{MPa})$ for briquettes made with TRY. This sample material cannot be used solely for dense brick manufacturing in the explored temperature range. For this temperature range, a need for an amendment is recommended. From PSD of this sample (Table II), increasing the silt content may be of interest for manufacturing of quality dense bricks. Hence, except for TRY $(\sigma<2 \mathrm{MPa})$, the others exhibited flexural strength values $>2 \mathrm{MPa}$ and can be used for structural brick manufacturing [34], in particular, firing at $1000{ }^{\circ} \mathrm{C}$ may be recommended. For lower temperatures, the flux amendment is needed. The sample SAN flexural strength was highest among the series and this value was justified by its clay content which was the highest. This high clay content favored densification resulting in more mullite formation upon firing that increased the strength. Considering the water adsorption (Fig. 9b), to conveniently use TAP and TRY, improving their clay content through mixing is needed. For a dimensional control, SAN shrinkage should be reduced by increasing its quartz content. For roofing tile application after firing at a temperature higher than $1000{ }^{\circ} \mathrm{C}, \mathrm{SAN}, \mathrm{MBE}$, and DOG1 with $\sigma \geq 5.7 \mathrm{MPa}$ and $\mathrm{WA}<20 \%$ are valuable materials for roofing tile manufacturing. However, a convenient amendment for improved flexural strength in the case of MBE or for dimensional control by reducing the shrinkage in the case of SAN is needed. Taking into consideration all the previous comments, some applications are given with minimal suggested firing temperature in Table IV.

Microstructure: a microstructural analysis was performed on samples usable for at least dense brick manufacturing. SAN briquette with good mechanical responses and DOG product with poor mechanical responses were chosen. In Fig. 10, the micrographs of the samples fired at 900, 1000 and $1100{ }^{\circ} \mathrm{C}$ are shown. The development of cracks was greater for DOG samples at all temperatures in comparison with SAN products. Also, the densification of the sample was less evidenced by DOG samples. Both observations were in accordance with the registered mechanical response. It is reported that excessive shrinkage generates dimensional problems that result in cracking [23]. In the reported shrinkage of this study, DOG samples exhibited low shrinkage when compared to SAN. As such, it is suggested that high quartz content prevent quality grain adhesion which resulted in cracks and pores development as seen on the micrographs (Figs. 10a to 10c). The micrographs of SAN (Figs. 10d to 10f) showed low cracking as compared to DOG and this was due to its high clay content. Also, both series of micrographs showed poor to almost absence 

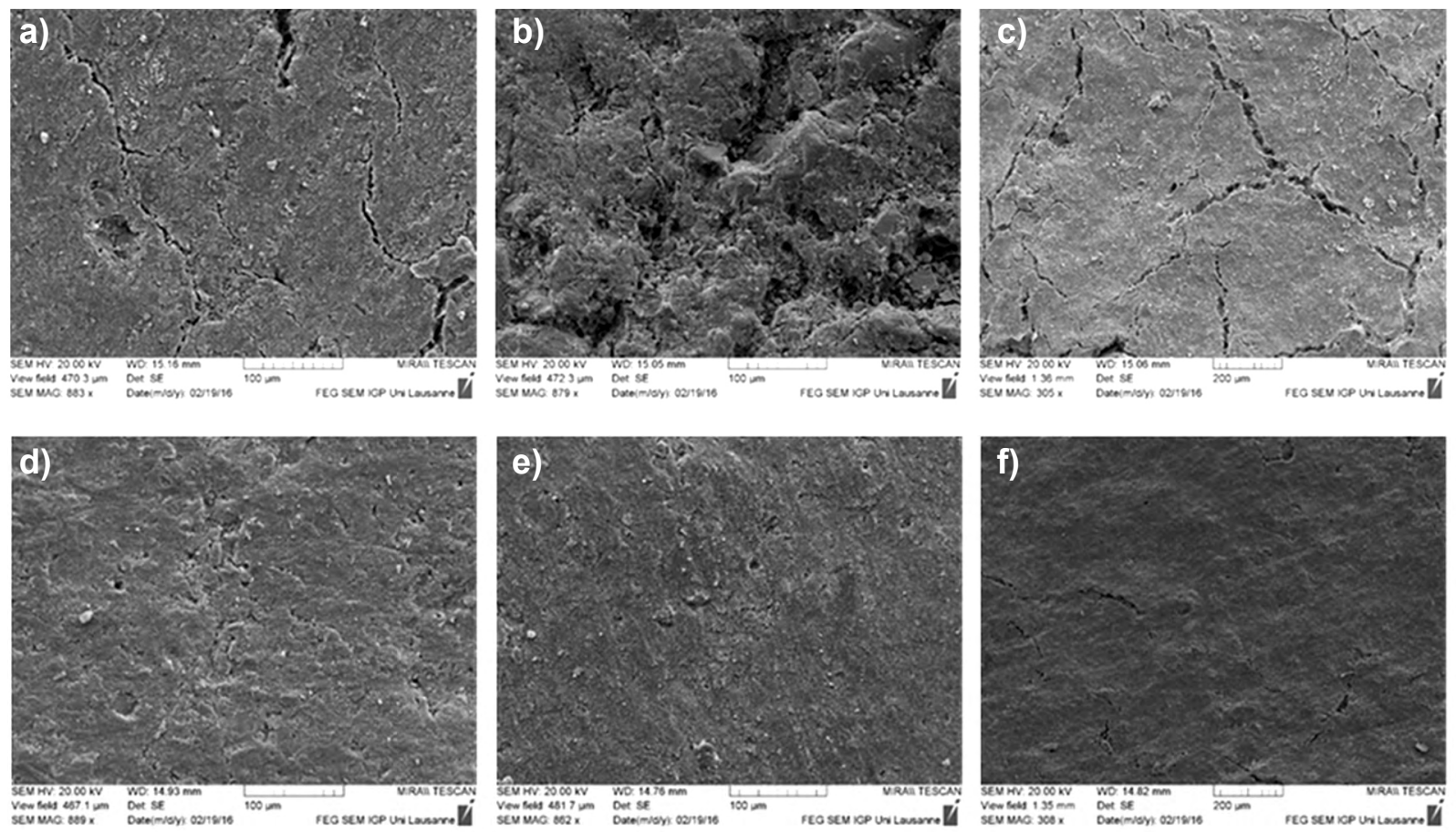

Figure 10: SEM micrographs of DOG (a-c) and SAN (d-f) bricks fired at $900{ }^{\circ} \mathrm{C}(\mathrm{a}, \mathrm{d}), 1000{ }^{\circ} \mathrm{C}(\mathrm{b}, \mathrm{e})$, and $1100{ }^{\circ} \mathrm{C}(\mathrm{c}, \mathrm{f})$.

[Figura 10: Micrografias de MEV de tijolos DOG (a-c) e SAN (d-f) queimados a $900{ }^{\circ} \mathrm{C}(a, d), 1000{ }^{\circ} \mathrm{C}(b, e) e 1100{ }^{\circ} \mathrm{C}(c, f)$.]

Table IV - Recommended applications and firing temperatures.

[Tabela IV - Aplicações recomendadas e temperaturas de queima.]

\begin{tabular}{ccc}
\hline Sample & $\begin{array}{c}\text { Recommended minimal } \\
\text { firing temperature }\left({ }^{\circ} \mathrm{C}\right)\end{array}$ & $\begin{array}{c}\text { Potential } \\
\text { application }\end{array}$ \\
\hline DOG & 1000 & $\begin{array}{c}\text { Structural brick } \\
\text { Structural brick; } \\
\text { roofing tile* }\end{array}$ \\
KAM & 950 & $\begin{array}{c}\text { Structural brick } \\
\text { Structural brick; } \\
\text { roofing tile } \\
\text { MBE }\end{array}$ \\
NGO & 950 & $\begin{array}{c}\text { Structural brick } \\
\text { Structural brick; } \\
\text { roofing tile } \\
\text { Structural }\end{array}$ \\
SAN & 950 & $\begin{array}{c}\text { brick after clay } \\
\text { amendment }\end{array}$ \\
TAP & 950 & - \\
TRY & $>1100$ & Structural brick \\
WAN & 1000 &
\end{tabular}

of vitrification. Hence low vitreous phase formation also accounted for poor densification resulting in cracked structures. It is recommended that, to be used in vitreous material manufacturing, the clay should be amended with a fluxing additive prior to its firing.

\section{CONCLUSIONS}

This study evaluated the potential ceramic applications of alluvial clays from Batouri area. The interest of this study was to throw light on the scientific information of the Batouri alluvial clayey materials as a key for their economical added value, particularly to improve their utilization for building material manufacturing. To achieve this effect, the mineralogy and chemical composition of nine clayey samples were analyzed. Briquettes were formulated and fired at 900, 950, 1000 and $1100{ }^{\circ} \mathrm{C}$ prior to some mechanical and physical testing. From XRD, FTIR and chemical analyses, these clays were found to be kaolinite-rich materials containing kaolinite, quartz, K-feldspars, anatase, and goethite, with very low content of fluxing oxides. The increase of the flexural strength was well corroborated by the formation of dense mineral phases such as mullite. However, poor vitreous phase formation influenced the cohesion of the fired products. The water absorption values increased with firing temperature and remained moderate $(<25 \%)$. The linear shrinkage was relatively large for SAN, MBE and DOG samples due to their high clay contents. Except for TRY clay, the flexural strength values of the fired products were higher than $2 \mathrm{MPa}$ at all firing temperatures. The large mullite phase formation in SAN fired product justified its highest flexural strength. From the SEM micrographs, crack formation on the fired bodies also confirmed the poor vitrification of the ceramics body in accordance with water adsorption or flexural strength measurements. These cracks and pores development were associated with the quartz (sand) contents of the samples that affected grain cohesion 
and led to poor mechanical response as observed for DOG fired product. From these results, it was proposed that these clays could be used for structural bricks (including dense bricks or perforated bricks), even though some amendments in clay and sand content are sometimes needed. In addition, roofing tiles could be produced using SAN, MBE, and DOG1 at a firing temperature higher than $1000{ }^{\circ} \mathrm{C}$ and after convenient amendment for dimensional control and water absorption reduction. In order to improve vitreous phase formation upon firing, the addition of fluxes is required for all the samples.

\section{ACKNOWLEDGMENTS}

The authors express their gratitude to the GeoLabs (Sudbury-Canada) for mineralogical and chemical analyses. Mr. Matemb Ma Ntep is greatly acknowledged for the XRD analyses of the fired products.

\section{REFERENCES}

[1] H.H. Murray, Appl. Clay Sci. 17 (2000) 207.

[2] H. Celik, Appl. Clay Sci. 50 (2010) 245.

[3] D. Njoya, M. Hajjaji, D. Njopwouo, Appl. Clay Sci. 6566 (2012) 106.

[4] M. Hajjaji, Commun. Geol. 101, 1 (2014) 75.

[5] F.H.-B. Zaied, R. Abidi, N. Slim-Shimi, A. Somarin, Appl. Clay Sci. 112-113 (2015) 1.

[6] B. Abdelmalek, B. Rekia, B. Youcef, B. Lakhdar, N. Fagel, Appl. Clay Sci. 136 (2017) 176.

[7] G.-I. Ekosse, Appl. Clay Sci. 50 (2010) 212.

[8] G.F. Ngon, R. Yongue-Fouateu, D.L. Bitom, P. Bilong, J. Afr. Earth Sci. 55 (2009) 69.

[9] C. Nkoumbou, A. Njoya, C. Grosbois, D. Njopwouo, J. Yvon, F. Martin, Appl. Clay Sci. 43 (2009) 118.

[10] M.L. Diko, G.-E. Ekosse, S.N. Ayonghe, E.E. Ntasin, Appl. Clay Sci. 51 (2011) 380.

[11] A.N. Nzeugang, N. Fagel, A. Njoya, V.K. Beyala, R.M. Eko, Appl. Clay Sci. 83-84 (2013) 238.

[12] S. Fadil-Djenabou, P.-D. Ndjigui, J.A. Mbey, J. Asian Ceram. Soc. 3 (2015) 50.

[13] R.F.D. Ntouala, V.L. Onana, V.K. Kabeyene, G.E. Ekodeck, J. Build. Eng. 5 (2016) 50.
[14] V.L. Onana, R.F.D. Ntouala, E. Ndome Effoudou, C.Y. Nguembou, A. Nguessi, V.K. Kabayene, J. Cameroon Acad. Sci. 13, 1-2 (2016) 23.

[15] J.E. Oti, J.M. Kinuthie, J. Bai, Eng. Geol. 107 (2009) 130.

[16] J.E. Oti, J.M. Kinuthie, Appl. Clay Sci. 58 (2012) 52.

[17] P.M. Velasco, M.P.M. Ortíz, M.A.M. Giró, L.M. Velasco, Constr. Build. Mater. 63 (2014) 97.

[18] A. Hashemi, H. Cruickshank, A. Cheshmehzangi, Sustainability 7, 6 (2015) 7866.

[19] A.V. Asaah, B. Zoheir, B. Lehmann, D. Frei, R. Burgess, C.E. Suh, Int. Geol. Rev. 57 (2015) 1485.

[20] A. Vishiti, C.E. Suh, B. Lehmann, J.A. Egbe, E.M. Shemang, J. Afr. Earth Sci. 111 (2015) 1.

[21] J.D.T. Wambo, S. Ganno, A.A. Ngambu, E.N. Negue, J.O. Mvondo, J.P. Nzenti, J. Geosci. Geomat. 4 (2016) 61.

[22] D.H. Gouet, A. Meying, S.P. Assembe, T. NdougsaMbarga, J. Geos. Environ. Protect. 3 (2015) 123.

[23] Clay Brick Ass. South Africa, in "Clay brick technical guide", ABC Press, Cape Town (2013) 1.

[24] C.M.F. Vieira, R. Sánchez, S.N. Monteiro, Constr. Build. Mater. 22 (2008) 781.

[25] H. Baccour, M. Medhioub, F. Jamoussi, T. Mhiri, A. Daoud, Mater. Charact. 59 (2008) 1613.

[26] R.L. Frost, É. Makó, J. Kristóf, E. Horváth, J.T. Kloprogge, Langmuir 17 (2001) 4731.

[27] J.A. Mbey, F. Thomas, C.J.N. Sabouang, Liboum, D. Njopwouo, Appl. Clay Sci. 83-84 (2013) 327.

[28] M.A. Qtaitat, I.N. Al-Trawneh, Spectrochim. Acta A Mol. Biomol. Spectrosc. 61 (2005) 1519.

[29] C. Fiori, B. Fabbri, G. Donati, I. Ventury, Appl. Clay Sci. 4 (1989) 461.

[30] J.A. Bain, D.E. Highley, Dev. Sedimentol. 27 (1979) 437.

[31] P.-D. Ndjigui, J.A. Mbey, A.N. Nzeukou, J. Build. Eng. 5 (2016) 151.

[32] A.N. Nzeugang, M. El Ouahabi, B. Aziwo, J.R. Mache, H.S.M. Mounton, N. Fagel, Clay Miner. 53 (2018) 563.

[33] H. Baccour, M. Medhioub, F. Jamoussi, T. Mhiri, J. Mater. Process. Technol. 209, 6 (2009) 2812.

[34] G.P. Souza, R. Sanchez, J.N.F. De Holanda, Cerâmica 48, 306 (2002) 102.

(Rec. 18/09/2018, Rev. 07/12/2018, 13/02/2019, Ac. 07/03/2019) 